\title{
Implications of differing input data sources and approaches upon forest carbon stock estimation
}

\author{
Michael A. Wulder • Joanne C. White • Graham Stinson • Thomas Hilker • \\ Werner A. Kurz • Nicholas C. Coops • Benôit St-Onge • J. A. (Tony) Trofymow
}

Received: 18 December 2008 / Accepted: 26 May 2009 / Published online: 11 June 2009

(C) Her Majesty the Queen in Right of Canada 2009

\begin{abstract}
Site index is an important forest inventory attribute that relates productivity and growth expectation of forests over time. In forest inventory programs, site index is used in conjunction with other forest inventory attributes (i.e., height, age) for the estimation of stand volume. In turn, stand volumes are used to estimate biomass (and biomass components) and enable conversion to carbon. In this research, we explore the implications and consequences of different estimates of site index on carbon stock characterization for a 2,500-ha Douglas-fir-dominated landscape located on Eastern Vancouver Island, British Columbia, Canada. We compared site index estimates from an existing forest inventory to estimates generated from a combination of
\end{abstract}

M. A. Wulder $(\varangle) \cdot$ J. C. White · G. Stinson ·

W. A. Kurz · J. A. (Tony) Trofymow

Canadian Forest Service (Pacific Forestry Center),

Natural Resources Canada, 506 West Burnside Rd.,

Victoria, BC V8Z 1M5, Canada

e-mail: mwulder@nrcan.gc.ca

T. Hilker · N. C. Coops

Department of Forest Resource Management,

University of British Columbia,

Vancouver, British Columbia, Canada

B. St-Onge

Department of Geography, Université of Québec

in Montréal, Montréal, Quebec, Canada forest inventory and light detection and ranging (LIDAR)-derived attributes and then examined the resultant differences in biomass estimates generated from a carbon budget model (Carbon Budget Model of the Canadian Forest Sector (CBM-CFS3)). Significant differences were found between the original and LIDAR-derived site indices for all species types and for the resulting 5 -m site classes $(p<0.001)$. The LIDAR-derived site class was greater than the original site class for $42 \%$ of stands; however, $77 \%$ of stands were within \pm 1 site class of the original class. Differences in biomass estimates between the model scenarios were significant for both total stand biomass and biomass per hectare $(p<0.001)$; differences for Douglas-fir-dominated stands (representing $85 \%$ of all stands) were not significant $(p=0.288)$. Overall, the relationship between the two biomass estimates was strong $\left(R^{2}=0.92, p<\right.$ 0.001 ), suggesting that in certain circumstances, LIDAR may have a role to play in site index estimation and biomass mapping.

Keywords Site index · LIDAR · Forest • Height • Age $\cdot$ Biomass $\cdot$ Carbon $\cdot$ Carbon budget model . Monitoring

\section{Introduction}

Carbon budget models often rely on forest inventories for assessment of stand type, forest 
growth, species composition, and other ecological criteria (Landsberg 2003). The Canadian Forest Service developed the Carbon Budget Model of the Canadian Forest Sector (CBM-CFS3), which uses empirical forest inventory growth curves to calculate stand-level biomass and biomass dynamics for Canada's forests (Kurz et al. 2002). Obtaining reliable forest inventory data is a laborious and costly process, and as a result, forest inventories are often based on sampling (Kangas et al. 2006). For example, Canada's new National Forest Inventory is based on a $1 \%$ sample of the 401.9 million hectare of Canada's forests and other wooded lands (Gillis et al. 2005). Aerial photography has played an important role in the development of forest inventories (Hall 2003), and more recently, light detection and ranging (LIDAR) instruments have emerged as useful tools for collecting vertical forest structure information (McRoberts and Tomppo 2007).

As the availability of LIDAR data has become more widespread, forest managers have seen opportunities for using LIDAR to meet a wider range of forest inventory information needs (Nelson et al. 2003). LIDAR data are used to produce accurate depictions of tree height (St-Onge et al. 2003) and structure (Lim et al. 2003) and, when collected with an appropriate density of hits on the ground (Lovell et al. 2005), may be used to generate accurate models of stand height (Næsset and Økland 2002).

Stand height and stand age are important attributes of forest inventories that provide a measure of potential site productivity, also known as site index. In British Columbia, site index is defined as the average height that a free-growing, undamaged, top-height tree of a given species can achieve at 50 years growth above-breast height (British Columbia Ministry of Forests 1999). A top-height tree is the largest tree (by diameter at breast height $(\mathrm{DBH})(1.3 \mathrm{~m}))$ of a given species in a 0.01-ha plot (British Columbia Ministry of Forests 1999). Site index is an important attribute for forest management, informing inventory, silviculture, timber supply analysis (Nigh and Love 1999), and carbon budget modeling, and is the most commonly used indicator of site produc- tivity (Hägglund 1981). The concept of site index is premised on the assumption that stand height (combined with age) is closely related to stand volume and is, therefore, a good proxy for assessing productivity (Avery and Burkhart 2002). Height growth is assumed to be sensitive to differences in site quality but not to variations in density, species composition, or thinning regimes.

In a silvicultural context, site index is used to characterize site quality, which in turn is required to formulate silvicultural prescriptions and predict stand growth and yield. In timber supply analyses, site index is used to estimate the number of years required for a harvested stand to be reestablished (i.e., a statutory requirement in British Columbia is that the average height of the tallest $10 \%$ of the trees is a minimum of $3 \mathrm{~m}$ ), the extent of the operable land base, the minimum harvestable age, the yield of regenerated stands, the growth of existing stands, and the supply of wood available for future harvesting. For inventory, site index is also used to characterize site quality, project inventory volume growth, and compare site potential across a range of stand conditions (British Columbia Ministry of Forests 1999; Stearns-Smith 2001; Avery and Burkhart 2002). Although site index is an important attribute for a wide range of forestry applications, the estimation of site index using data sources other than a combination of air photo interpretation and fieldwork has not received much attention from the remote sensing community.

The objectives of this research are to present an approach using LIDAR-derived mean stand top height combined with other photo-interpreted forest inventory attributes to estimate site index $\left(\mathrm{SI}_{\text {LIDAR }}\right)$ and then compare these estimates to existing forest inventory site-index values ( $\left.\mathrm{SI}_{\mathrm{INV}}\right)$. $\mathrm{SI}_{\text {LIDAR }}$ are used as inputs to CBM-CFS3 to model forest biomass, and the model outputs are compared to model outputs generated using $\mathrm{SI}_{\mathrm{INV}}$, with all other model parameters being equal. Biomass estimates from both CBM-CFS3 model scenarios are compared using all forest stands collectively and using strata defined by dominant tree species. 


\section{Background}

Site index

As a forest inventory attribute, site-index values may be adjusted as part of a forest inventory update process, which is typically conducted on a 10-year cycle in Canada (Gillis and Leckie 1996). Site index is calculated based on breast height age rather than total age; total age is the number of years since seed germination, while years to breast height is the number of years required for a tree to grow from seed to breast height. Breast height age is defined as the number of years of growth above breast height (British Columbia Ministry of Forests 1999). Several different methods are currently used to estimate site index, typically involving either the direct measurement of site trees or, more commonly, indirect estimation based on site factors. For example, in British Columbia, one of the three methods is generally used to estimate site index: height-age models, growth intercept models, and Site Index Biogeoclimatic Ecosystem Classification (SIBEC) models (Mah and Nigh 2003). Each method is most appropriate for a specific stage of stand development, and not all methods are applicable in all areas of the province.

Height-age models (the method applied in this study and hereafter referred to as the site index curve method) estimate site index from tree height and breast height age data and are applicable to stands that have 30 to 140 years of growth above breast height (British Columbia Ministry of Forests 1999). Site index curves are developed either from field measures in permanent sample plots (e.g., Bruce 1981) or from stem analysis (e.g., Nigh and Courtin 1998). A different model must be used for each species, as each species has a different height-age relationship (e.g., Nigh and Courtin 1998; Nigh and Love 1999; Nigh and Mitchell 2003). The site index curve method is known to underestimate site index for oldgrowth stands, leading to the development of a system of correction equations for several important softwood species (Nussbaum 1998) and the exploration of different approaches for site index estimation (Mah and Nigh 2003).
Forest inventory

Forest inventories are typically generated by the delineation of homogenous land cover types (i.e., polygons or stands) on aerial photographs, followed by the estimation or interpretation of forest attributes with the aid of ancillary data sources such as silvicultural surveys or ground plots. Typically, stand age and height are estimated directly from aerial photographs, while site index is derived from projected age, height, and species information using one of the aforementioned estimation methods to provide the best available estimate of site productivity (Stearns-Smith 2001). Certain inventory attributes are projected forward to represent stand conditions at a future date other than the date at which the data were originally recorded. Once projected, the inventory may then be used in applications such as timber supply or carbon budget modeling.

Stand age and height are two attributes that are "grown forward" in order to represent current stand conditions, while site index remains static. For example, if a forest inventory was completed in 1958, stand age and height would be projected to represent stand conditions in 2008. It is relatively straightforward to project age by simply adding the appropriate number of years to the original stand age (i.e., if the stand age in our example was 20 years in 1958, 50 years would be added to reflect 2008 conditions, and the projected age would be recorded as 70 years). Stand height is more difficult to project, since the height increment over the time period in question will vary with site conditions (Sharma and Parton 2007).

In general, projected age is used with speciesspecific site index functions to estimate projected height. There are three problems with this approach. First, site index functions are based on a generalized subsample of sites for a given species and are not site-specific, resulting in bias in the projection of height (Hasenauer and Monserud 1997). Second, research has documented that regenerating stands may have a higher site index than indicated in the forest inventory (which was determined based on the original stand conditions; Boyer 2001; Huang et al. 2004). Thus, site 
productivity is not static (Skovsgaard and Vanclay 2007) and in a site with stand replacing disturbance regimes (fire, harvesting), the original site index estimate may no longer reflect true site productivity (Stearns-Smith 2001). Third, photogrammetric methods for estimating tree height are prone to error under certain stand conditions, as it is often impossible to measure ground elevation near trees growing in dense forest (St-Onge et al. 2004; Véga and St-Onge 2008). Any error in the original photogrammetric estimate of height is propagated in the original estimation of site index, thereby impacting height projections when the inventory is grown forward.

\section{LIDAR}

Unlike passive remote sensing systems, LIDAR uses active laser pulses to capture the vertical structure of forest canopies. These emitted laser pulses are reflected from the terrain or from objects on the terrain, such as vegetation or buildings. The reflected pulses can be categorized as either first or last pulse returns (Lim et al. 2003). Although LIDAR pulses interact with the terrain and all materials above the ground to produce a complex cloud of points, increasingly reliable post-processing procedures for distinguishing between ground and object points are being implemented (e.g., Roggero 2001; Sithole and Vosselman 2004; Chen et al. 2007). More advanced LIDAR systems allow multiple returns to be recorded for each emitted pulse.

The distance between the LIDAR source and the point of reflectance is determined by measuring the time required for a light beam to travel from sensor to the surface and back to the sensor. Tree heights can be computed from calculating the difference between the ground (last pulse returns) and top of canopy (first pulse returns) when the position and three-dimensional angle of the instrument is known (either from satellite Global Positioning Systems (GPS) and/or Inertial Navigation Systems (INS) measurements; Véga and St-Onge 2008). The error associated with LIDAR measurements of tree height are typically between 0.5 and $1.0 \mathrm{~m}$ (Persson et al. 2002; Næsset 1997, 2002; Magnussen and Boudewyn 1998; Magnussen et al. 1999; Næsset and Økland 2002), and LIDAR is considered more accurate for height measurement than common field-based measurements (Næsset and Økland 2002).

The greatest advantage of LIDAR is the direct measurement of vertical forest structure (Dubayah and Drake 2000). LIDAR data (either as a direct measure or as a data input for modeling) have been used to characterize forest attributes such as stand height (Næsset et al. 2005), canopy structure (Ni-Meister et al. 2001), crown closure (Lim et al. 2003), biomass (Popescu 2007), and canopy volume (Lefsky et al. 2005; Coops et al. 2007; Heo et al. 2008). Although LIDAR has largely been used for collecting highresolution geospatial data over vegetated areas, only in the last few years have natural resource scientists begun to use LIDAR for forest structure mapping and inventory purposes (Reutebuch et al. 2003).

There are few examples where LIDAR has been used for large-scale forest inventories (Nelson et al. 2003; Næsset et al. 2005), and analysis procedures for LIDAR in a forestry context are not yet as refined as procedures used for terrain mapping products (Reutebuch et al. 2005). Forest inventory assessment from LIDAR is often based on extraction of individual tree heights (Popescu et al. 2002; Popescu and Wynne 2004) and application of spatial rules for extrapolating this information across the landscape. A first explicit example of site-index estimation from LIDAR was introduced by Gatziolis (2007) using canopy and ground models for establishing plotbased site-index measures for Douglas-fir from LIDAR-derived canopy and ground models. A recent study by St-Onge et al. (2008) was able to map tree height and aboveground biomass by integrating stereo IKONOS images and LIDAR.

\section{Carbon budget modeling}

Forests exchange large quantities of $\mathrm{CO}_{2}$ with the atmosphere and make an important contribution to the global biogeochemical cycling of carbon (C) (Hamilton et al. 2002; Denman et al. 2007). Various approaches have been developed to assess forest ecosystem $\mathrm{C}$ exchange, from the measurement of temporal changes in biomass (Clark et al. 2001) and soil C (Lal et al. 2001) to the measurement 
of $\mathrm{C}$ exchanges themselves using eddy covariance flux towers (Baldocchi 2003). Although these approaches have been used to assess $\mathrm{C}$ exchange for a large number of forest sites around the world, these measurements are not necessarily representative of entire landscapes (Running et al. 1999); hence, the description of regional or biome-level ecosystem $\mathrm{C}$ dynamics remains difficult (Aalde et al. 2006).

A number of simulation modeling approaches have been developed to estimate forest ecosystem $\mathrm{C}$ fluxes at different spatial and temporal scales, including both process-driven and empirically driven forest ecosystem simulation models (Landsberg 2003). The latter typically involves the use of empirical information on the growth and yield of merchantable wood volume as input to estimate tree biomass $\mathrm{C}$ dynamics. This is the approach that is employed in CBM-CFS3, which takes merchantable wood volume yield tables as input and uses this information together with forest inventory data and a system of biomass estimation models (Boudewyn et al. 2007) to simulate tree biomass $\mathrm{C}$ dynamics. In general, yield tables describe merchantable wood volume increment as a function of stand age. Thousands of such tables have been compiled by the forest management community in Canada for timber supply analysis purposes and for use in forest management planning tools (Kurz et al. 2002). These yield tables, based on data collected at thousands of permanent sample plots across Canada, provide the foundation for tree biomass $\mathrm{C}$ dynamics in the CBM-CFS3 model. The strength of this approach is that CBM-CFS3 is capable of generating estimates of tree growth that are consistent with field measurements; however, the model cannot account for interannual variability in tree growth or long-term changes in tree growth rates unless additional data and methods are used to apply adjustments to the base growth rates prescribed by the yield tables.

Merchantable volume yield tables are typically produced for forest strata that include a range of forest stand types, and for modeling purposes, these strata are assumed to have the same growth dynamics. Forest inventory polygons are commonly assigned to growth strata on the basis of stand attributes such as site index, species mix, and other ecological criteria. For the purposes of stratification, continuous variables such as site index are often categorized into 5-m site classes or into even more generalized groupings such as high, medium, and poor sites. Errors in the estimation of site index that result in forest polygons being assigned to the wrong site class will also cause the wrong yield table to be assigned to those polygons.

\section{Study area}

The study was conducted in the Oyster River area located between Courtenay and Campbell River on the eastern side of Vancouver Island, British Columbia, Canada (Fig. 1). The bounds of the $5 \times$ $5-\mathrm{km}$ study area were chosen to encompass available inventory data, historic mapped disturbance data, and two flux tower sites (DF1949, HDF2000) and one meteorological tower site (HDF1990) of the Fluxnet Canada Research Network coastal British Columbia station (Humphreys et al. 2006). The Oyster River area is within the dry maritime Coastal Western Hemlock biogeoclimatic subzone (CWHxm) spanning the east (CWHxm1) and west (CWHxm2) variants of the subzone with annual precipitation averaging $1500 \mathrm{~mm}$ and a mean annual temperature of 9.1 degrees Celcius (Pojar et al. 1991). This subzone has a maritime climate with typically cool summers and mild winters, though this area can experience significant dry conditions during the summer.

The study area spans the transition from the Nanaimo Lowlands and Leeward Island Mountain Ecosections (Demarchi 1996), ranging in elevation from 120 to $460 \mathrm{~m}$ and is within 10 to $15 \mathrm{~km}$ from the coast. Douglas-fir (Pseudotsuga menziesii var menziesii (Mirb.) Franco) is the dominant tree species on dry to mesic site series, though wetter site series will contain western redcedar (Thuja plicata Donn ex D. Don) and western hemlock (Tsuga heterophylla (Raf.) Sarg.), with amabilis fir (Abies amabilis) at higher elevations (Green and Klinka 1994). Patches of red alder (Alnus rubra Bong.) dominated or hardhack-sweet gale (Spirea douglasii ssp. Douglasii-Myrica gale) wetlands are also 
Fig. 1 Study area location on Vancouver Island, British Columbia, Canada

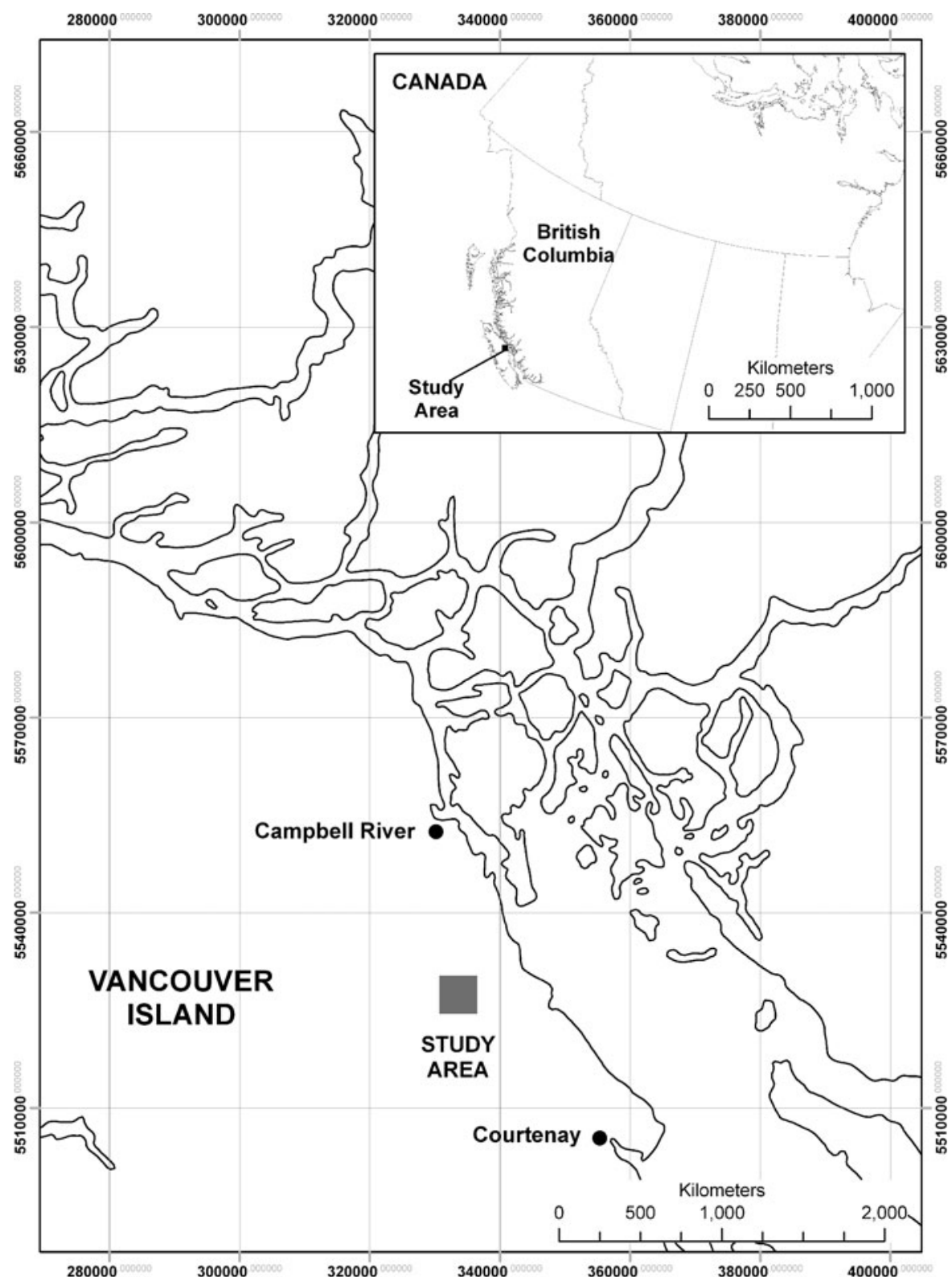

Table 1 Summary of leading species by area and by proportion of inventory stands

\begin{tabular}{|c|c|c|c|c|c|c|c|c|}
\hline \multirow[t]{2}{*}{ Leading species } & \multicolumn{4}{|c|}{ All forest inventory stands in the study area } & \multicolumn{4}{|c|}{ Forested stands with age $30-140$ years } \\
\hline & $\begin{array}{l}\text { Area } \\
\text { (ha) }\end{array}$ & $\begin{array}{l}\text { Proportion } \\
(\%)\end{array}$ & $\begin{array}{l}\text { \# of } \\
\text { Stands }\end{array}$ & $\begin{array}{l}\text { Proportion } \\
(\%)\end{array}$ & $\begin{array}{l}\text { Area } \\
\text { (ha) }\end{array}$ & $\begin{array}{l}\text { Proportion } \\
(\%)\end{array}$ & $\begin{array}{l}\text { \# of } \\
\text { Stands }\end{array}$ & $\begin{array}{l}\text { Proportion } \\
(\%)\end{array}$ \\
\hline Amabilis fir & 30 & 1.20 & 31 & 1.34 & 18 & 0.68 & 9 & 1.10 \\
\hline Western redcedar & 4 & 0.14 & 10 & 0.43 & 3 & 0.68 & 9 & 0.17 \\
\hline Red alder & 259 & 10.35 & 334 & 14.46 & 203 & 17.35 & 229 & 12.32 \\
\hline Douglas-fir & 2050 & 82.01 & 1652 & 71.52 & 1399 & 79.24 & 1046 & 84.90 \\
\hline Western hemlock & 84 & 3.38 & 112 & 4.85 & 25 & 2.05 & 27 & 1.51 \\
\hline Non-forest & 73 & 2.92 & 171 & 7.40 & N/A & N/A & N/A & N/A \\
\hline TOTAL & 2,500 & 100.00 & 2,310 & 100.00 & 1,648 & 100.00 & 1,320 & 100.00 \\
\hline
\end{tabular}


found throughout the area, especially at lower elevations. The distribution of leading species in the study area is summarized in Table 1. Soils within the area range from very gravelly textured duric humo-ferric podzols of fluvial origin at low elevations, to gravelly sandy loam textured duric humo-ferric and ferro-humic podzols of morainal origin at intermediate elevations to shallow stony ortho humo-ferric podzols on colluvium on higher elevation hilltops (Jungen 1985).

\section{Data}

\section{Forest inventory}

Most of the forest stands within the area are found on private land managed for timber production by Timberwest and Island Timberlands (formerly Weyerhaeuser) and consist predominantly of forests regenerating from clearcut harvest. Each company maintained its own forest inventory data for its respective area within the Oyster River study site, and these inventories (all current to 1999) were harmonized and compiled into a single database (Trofymow et al. 2008) by matching the edges of the inventories with cadastral boundaries and common 1:20,000 Terrain Resource Information Management (TRIM) base map (British Columbia Ministry of Environment, Lands, and Parks 1992). The combined forest inventory contained information on tree species, year of stand establishment, codes for analysis units, site index, and non-forest land cover. Stands were updated for depletion using 1:70,000 orthophotography acquired in 1995 and 1999 and using spatial information on harvest blocks obtained from the forest companies in 2005. Site index was used to estimate growth and yield over time (Personal communication: Jim McPhalen, Timberwest), and stand volume tables were generated from the British Columbia Ministry of Forests Variable Density Yield Projection (VDYP) (British Columbia Ministry of Forests 1996) program for natural stands or the Table Interpolation Program for Stand Yield (TIPSY; Mitchell et al. 2000) program for managed stands.
LIDAR data and processing

Small footprint laser data were acquired June 8, 2004 using Terra Remote Sensing's LIDAR instrument on a Bell 206 Jet Ranger helicopter. In Table 2, we provide details on the LIDAR system configuration used for data collection. Based on the pulse frequency and the lowest sustainable flight speed and altitude, hit densities of $0.7 \mathrm{hit} / \mathrm{m}^{2}$ were achieved with a footprint (spot size) of $0.19 \mathrm{~m}$. Separation of vegetation (nonground) and terrain (ground) hits was carried out using Terrascan v. 4.006 software (Terrasolid, Helsinki, Finland), which uses iterative algorithms that combine filtering and thresholding methods (Kraus and Pfeiffer 1998; Axelsson 1999) to classify the LIDAR data into either ground or nonground returns.

From these data, a canopy height model (CHM), describing the three-dimensional canopy structure, was derived in two steps: first, a digital elevation model was developed using ground classified LIDAR returns to establish a triangular irregular network (TIN), which was then rasterized at a $0.5 \mathrm{~m}$ spatial resolution. Similarly, a TIN and subsequently a raster $(0.5 \mathrm{~m}$ spatial resolution) were generated for the non-ground returns. Second, a CHM was generated by subtracting the interpolated ground elevations from the interpolated non-ground elevations.

Table 2 LIDAR acquisition parameters

\begin{tabular}{ll}
\hline Parameter & Performance \\
\hline Sensor & Mark II \\
Laser scan frequency & $25 \mathrm{~Hz}$ \\
Laser impulse frequency & $40,000 \mathrm{~Hz}$ \\
Laser power & $<4 \mathrm{~W}$ \\
Maximum scan angle & $<20^{\circ}$ \\
Type of scanning mirror & Oscillating \\
Laser beam divergence & $<0.5 \mathrm{mrad}$ \\
Measurement density & $0.5-0.8$ hits $/ \mathrm{m}^{2}$ \\
Datum & $\mathrm{NAD} 83$ \\
Projection & $\mathrm{UTM}$ Zone 10 \\
Platform & Bell $206 \mathrm{Jet}$ \\
& ranger helicopter \\
Flight altitude above ground & $900 \mathrm{~m}$ \\
Flight speed & $25-30 \mathrm{~m} \mathrm{~s}^{-1}$ \\
Version of TerraScan & Version 004.006 \\
used to classify & \\
\hline
\end{tabular}




\section{Methods}

\section{Stand height estimation}

The correct estimation of top height is critical to the calculation of site index. The Forest Productivity Council of British Columbia (1998a) defines top height as the height of the largest diameter tree in a 0.01-ha plot, providing the tree is suitable (i.e., the tree is healthy, it does not have a broken or damaged top, and its growth is not suppressed by a competitor). The largest diameter tree is used rather than the tallest tree, as the former is easier to identify, measure, and audit in the field, plus there is typically less error associated with measuring DBH. This definition of top height prevents situations where all of the top-height trees are clustered in a single location within a 1-ha area (Forest Productivity Council of British Columbia 1998b). Research on the impact of plot size on the definition of top height has concluded that top height is sensitive to plot size (Magnussen 1999; García and Batho 2005), therefore the application of a consistent top-height definition is an important factor for forest management in general and for site index estimation in particular.

The estimation of tree height and stand height from LIDAR data has been the subject of extensive research (for summary, see Lim et al. 2003). When mean stand height is computed from field measurements, the heights of individual trees are typically weighted according to their basal area (Lorey's mean height); therefore, larger trees have a greater impact on the estimation of mean stand height. A similar approach can be implemented with the LIDAR by using only the largest heights in the stand; however, the $n$th largest heights may not be spatially representative of the stand as a whole. Therefore, it is necessary to use a method that can account for spatial variability in the stand. Imposing restrictions for spatial representation may be achieved by superimposing a tessellation of grid cells to the stand and using these grid cells to acquire spatially representative samples of LIDAR hits from across the stand in the calculation of mean stand height (Næsset 1997).

Næsset (1997) found that a direct average of all the non-ground LIDAR hits within a stand re- sulted in an underestimation of ground measured mean stand height by 4.1 to $5.5 \mathrm{~m}$. By applying a regular sample grid to the stands, systematically selecting only the largest heights within each grid cell and calculating a weighted-average stand height (with the number of non-ground LIDAR hits per grid cell used as weights), the LIDAR estimates more closely matched the field measurements (with errors ranging from -0.4 to $1.9 \mathrm{~m}$ ). Magnussen and Boudewyn (1998) also demonstrated that the use of a sample grid and the maximum height within each grid cell results in mean stand height values that more closely match ground estimates. In this study, we implemented Næsset's approach (1997), applying a $10 \times 10-\mathrm{m}$ grid over the study area and identifying the maximum height within each 0.01-ha grid cell. This approach to estimating mean stand top height from the LIDAR data was used because it most closely follows the operational definition of top height currently used in British Columbia (Forest Productivity Council of British Columbia 1998a, b). Stand height was, therefore, determined for each forest inventory polygon in the study area by determining the number of non-ground LIDAR returns and the maximum tree height within each 0.01-ha grid cell and then calculating the mean of the maximum heights, weighted by the number of non-ground LIDAR hits within each of the 0.01-ha grid cells.

\section{Site index estimation}

Operational procedures used for site index estimation were followed as closely as possible to ensure a robust comparison between the LIDARderived estimates of site index and the preexisting site-index values in the forest inventory. SiteTools software (version 3.3, British Columbia Ministry of Forests and Range 2004) was used to calculate site index for each of the forest stands. SiteTools supports both the growth-intercept method and the site-index curve method of site-index estimation (British Columbia Ministry of Forests and Range 2004). SiteTools requires species information and an estimate of stand height and age. Breast-height age is used for site index estimation, and SiteTools adjusts total age input from the forest inventory to breast-height age. For this 
study, stands with a projected age between 30 and 140 years were selected for comparison (based on age distribution of stands in the study area) so that the method of site index estimation (i.e., site index curve method) was consistent between $\mathrm{SI}_{\mathrm{INV}}$ and $\mathrm{SI}_{\text {LIDAR }}$. Other information required for estimation, such as species and projected age, were taken from the forest inventory. Compilation of ancillary data sources, as detailed in Trofymow et al. (2008), were used to capture disturbance

Table 3 Merchantable volume yield tables used to simulate aboveground biomass C dynamics in managed Douglas-firleading stands

\begin{tabular}{|c|c|c|c|c|c|c|c|c|}
\hline Age & $\begin{array}{l}\text { TI0110 } \\
\text { Site class } 10 \\
\mathrm{~m}^{3} \mathrm{ha}^{-1}\end{array}$ & $\begin{array}{l}\text { TI0115 } \\
\text { Site class } 15 \\
\mathrm{~m}^{3} \mathrm{ha}^{-1}\end{array}$ & $\begin{array}{l}\text { TI0120 } \\
\text { Site class } 20 \\
\mathrm{~m}^{3} \mathrm{ha}^{-1}\end{array}$ & $\begin{array}{l}\text { TI0125 } \\
\text { Site class } 25 \\
\mathrm{~m}^{3} \mathrm{ha}^{-1}\end{array}$ & $\begin{array}{l}\text { TI0130 } \\
\text { Site class } 30 \\
\mathrm{~m}^{3} \mathrm{ha}^{-1}\end{array}$ & $\begin{array}{l}\text { TI0135 } \\
\text { Site class } 35 \\
\mathrm{~m}^{3} \mathrm{ha}^{-1}\end{array}$ & $\begin{array}{l}\text { TI0140 } \\
\text { Site class } 40 \\
\mathrm{~m}^{3} \mathrm{ha}^{-1}\end{array}$ & $\begin{array}{l}\text { TI0145 } \\
\text { Site class } 45 \\
\mathrm{~m}^{3} \mathrm{ha}^{-1} \\
\end{array}$ \\
\hline 0 & 0 & 0 & 0 & 0 & 0 & 0 & 0 & 0 \\
\hline 5 & 0 & 0 & 0 & 0 & 0 & 0 & 0 & 0 \\
\hline 10 & 0 & 0 & 0 & 0 & 0 & 0 & 0 & 0 \\
\hline 15 & 0 & 0 & 0 & 0 & 0 & 1 & 21 & 48 \\
\hline 20 & 0 & 0 & 0 & 1 & 23 & 53 & 95 & 155 \\
\hline 25 & 0 & 0 & 5 & 35 & 71 & 131 & 197 & 271 \\
\hline 30 & 0 & 1 & 30 & 78 & 138 & 213 & 297 & 410 \\
\hline 35 & 0 & 13 & 59 & 132 & 202 & 292 & 413 & 542 \\
\hline 40 & 0 & 28 & 88 & 182 & 261 & 383 & 521 & 668 \\
\hline 45 & 1 & 43 & 125 & 225 & 324 & 470 & 620 & 788 \\
\hline 50 & 1 & 59 & 158 & 264 & 388 & 544 & 717 & 888 \\
\hline 55 & 7 & 74 & 185 & 302 & 449 & 617 & 802 & 977 \\
\hline 60 & 13 & 89 & 210 & 344 & 501 & 685 & 875 & 1,053 \\
\hline 65 & 19 & 108 & 233 & 382 & 548 & 749 & 941 & 1,121 \\
\hline 70 & 24 & 124 & 254 & 419 & 595 & 802 & 998 & 1,194 \\
\hline 75 & 29 & 139 & 274 & 453 & 638 & 850 & 1,049 & 1,261 \\
\hline 80 & 33 & 153 & 293 & 483 & 679 & 893 & 1,094 & 1,320 \\
\hline 85 & 38 & 165 & 314 & 510 & 716 & 933 & 1,141 & 1,361 \\
\hline 90 & 43 & 176 & 333 & 534 & 750 & 967 & 1,187 & 1,361 \\
\hline 95 & 47 & 185 & 350 & 557 & 779 & 999 & 1,229 & 1,361 \\
\hline 100 & 52 & 195 & 367 & 579 & 805 & 1,027 & 1,268 & 1,361 \\
\hline 105 & 56 & 203 & 383 & 601 & 829 & 1,053 & 1,298 & 1,361 \\
\hline 110 & 60 & 211 & 399 & 620 & 851 & 1,076 & 1,322 & 1,361 \\
\hline 115 & 63 & 218 & 413 & 638 & 872 & 1,101 & 1,343 & 1,361 \\
\hline 120 & 67 & 226 & 426 & 655 & 891 & 1,126 & 1,343 & 1,361 \\
\hline 125 & 70 & 232 & 438 & 671 & 908 & 1,149 & 1,343 & 1,361 \\
\hline 130 & 73 & 238 & 449 & 686 & 923 & 1,170 & 1,343 & 1,361 \\
\hline 135 & 75 & 244 & 459 & 699 & 937 & 1,189 & 1,343 & 1,361 \\
\hline 140 & 78 & 249 & 468 & 712 & 950 & 1,206 & 1,343 & 1,361 \\
\hline 145 & 81 & 254 & 476 & 723 & 961 & 1,223 & 1,343 & 1,361 \\
\hline 150 & 85 & 259 & 484 & 732 & 972 & 1,237 & 1,343 & 1,361 \\
\hline 155 & 88 & 263 & 491 & 741 & 982 & 1,246 & 1,343 & 1,361 \\
\hline 160 & 91 & 267 & 498 & 749 & 991 & 1,254 & 1,343 & 1,361 \\
\hline 165 & 94 & 272 & 504 & 757 & 999 & 1,262 & 1,343 & 1,361 \\
\hline 170 & 97 & 277 & 510 & 764 & 1,007 & 1,269 & 1,343 & 1,361 \\
\hline 175 & 99 & 281 & 516 & 771 & 1,014 & 1,269 & 1,343 & 1,361 \\
\hline 180 & 102 & 286 & 522 & 777 & 1,020 & 1,269 & 1,343 & 1,361 \\
\hline 185 & 104 & 290 & 528 & 782 & 1,028 & 1,269 & 1,343 & 1,361 \\
\hline 190 & 106 & 293 & 533 & 787 & 1,035 & 1,269 & 1,343 & 1,361 \\
\hline 195 & 108 & 297 & 537 & 792 & 1,042 & 1,269 & 1,343 & 1,361 \\
\hline 200 & 110 & 300 & 542 & 797 & 1,048 & 1,269 & 1,343 & 1,361 \\
\hline
\end{tabular}

All input data and modeling parameters used to conduct these simulations are described by Trofymow et al. (2008) 
information and update the "date of stand establishment" attribute. Current-age information was then determined by subtracting this revised date of stand establishment from 2006. There were 2310 forest stands in the study area; 1320 of these stands were productive forest with a projected total age between 30 and 140 years, with sufficient LIDAR data (>200 non-ground LIDAR hits/ha) to estimate stand height. This subset of 1320 forest inventory polygons was used to compare the siteindex values and subsequent CBM-CFS3 outputs.

\section{Estimation of stand biomass and C stocks}

Total stand biomass and $\mathrm{C}$ stocks and components (i.e., above- and below-ground biomass, dead wood, litter, and soil organic matter) were estimated using the CBM-CFS3, an annual timestep model that uses forest inventory data along with merchantable volume yield tables to drive stand-level biomass C dynamics (Kurz et al. 1992; Kurz and Apps 1999; Kurz et al. 2002; Kull et al. 2006). In this study, stand-level biomass carbon dynamics were simulated using merchantable volume yield tables derived for natural and managed stands in Coastal British Columbia, stratified by leading species and 5-m site index classes. The yield tables used for managed Douglas-fir leading stands (the most common stand type present in the study area) are provided in Table 3. Other yield tables were used for other stand types present in the study area, including hemlock-, red cedar-, amabilis-, and alder-dominated stands. These yield tables were developed by the British Columbia Ministry of Forests and Range using the Table Interpolation Program for Stand Yields (TIPSY) developed from the TASS individual tree growth model (Mitchell et al. 2000). In this application of the CBM-CFS3, each forest cover polygon in the forest inventory is treated as a separate database record and is assigned a yield table on the basis of stand type (defined according to species mix) and 5-m site class (Kurz et al. 2002). For CBM-CFS3, the continuous site-index values for $\mathrm{SI}_{\mathrm{INV}}$ and $\mathrm{SI}_{\text {LIDAR }}$ were categorized into 5-m site classes (SC), with the site-index values assigned to the closest 5-m interval (e.g., a site index of 12.4 is assigned a site class of 10 ; a site index of 12.5 is assigned a site class of 15) to generate $\mathrm{SC}_{\mathrm{INV}}$ and $\mathrm{SC}_{\text {LIDAR }}$.

Merchantable volume yields are converted in the model to annual above-ground biomass carbon (C) increments referenced to projected stand age using stand-level biomass estimation models (Boudewyn et al. 2007) and assuming a C content of $0.5 \mathrm{t} \mathrm{C} \mathrm{t}^{-1}$ biomass. Below-ground (root) biomass is estimated in the model as a function of aboveground biomass and species group (Li et al. 2003). CBM-CFS reports in units of tonnes C, and this is multiplied by two to get biomass (tonnes). The entire study area has been logged at least once since 1920 , so the entire stand history was simulated for all stands present on the landscape.

\section{Results}

Stand height and site-index estimation

Mean stand heights were determined for each forest stand. Although no field measures were available for comparison at this study site, Coops et al. (2007), working in a similar area with similar species, data, and methods for establishing mean plot height from LIDAR, found that LIDAR estimates of plot height were consistently lower than field-measured plot heights. As both the site index and modeled biomass estimates were generated from different data sources, they were expected to vary. The distribution of $\mathrm{SI}_{\mathrm{INV}}$ and $\mathrm{SI}_{\text {LIDAR }}$ for all 1320 stands is shown in Fig. 2. Regressions of $\mathrm{SI}_{\text {INV }}$ on $\mathrm{SI}_{\text {LIDAR }}$ produced a low overall $R^{2}$ value of $0.03(p<0.001$; Fig. 3$)$ and the stand-level differences between $\mathrm{SI}_{\mathrm{INV}}$ and $\mathrm{SI}_{\text {LIDAR }}$ were found to be statistically significant (dependent samples, two-tailed $t$-test, $\alpha=0.05, t=-9.224, p<0.001$, $d f=1,319)$. Figure 4 characterizes the differences between site index estimates by leading species; statistically significant differences were found for all leading species except western red cedar leading stands, which also had the largest standard error (Table 4). SI $_{\text {LIDAR }}$ are greater than the $\mathrm{SI}_{\text {INV }}$ for all stands sampled and for all species groups.

The site-index values were reclassified into 5-m site classes for input into CBM-CFS3. The relationship between $\mathrm{SC}_{\mathrm{INV}}$ and $\mathrm{SC}_{\mathrm{LIDAR}}$ was weak $\left(R^{2}=0.02, p<0.001\right)$, and there was a significant 
Fig. 2 Comparison of the distribution of site index estimates in the original forest inventory and the site index estimates made using LIDAR-derived mean stand heights

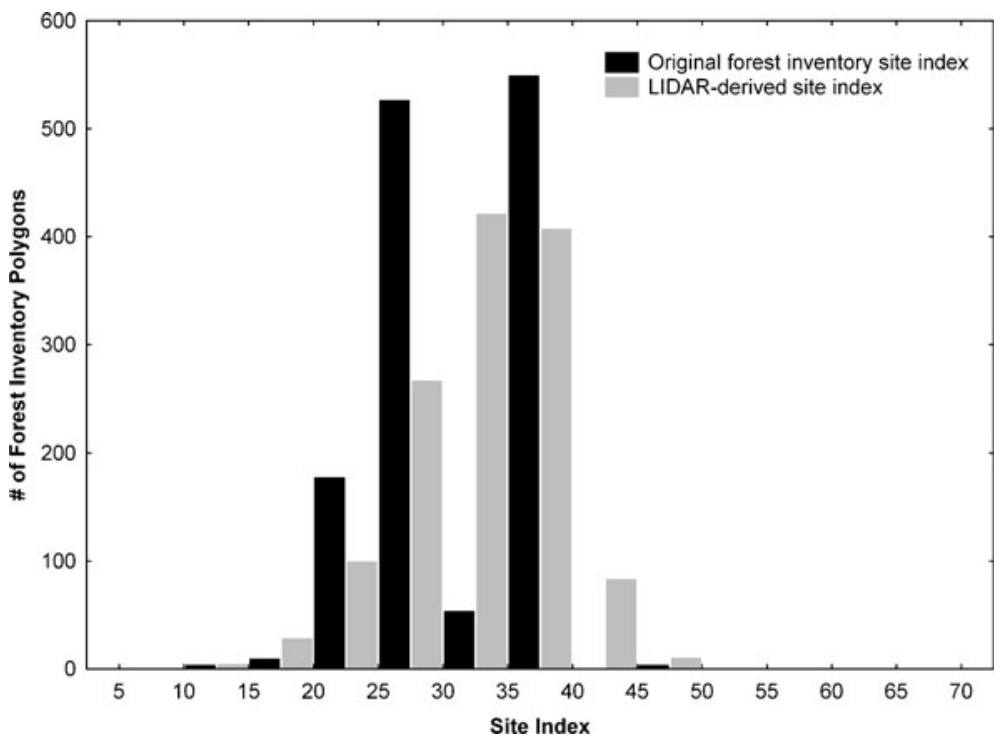

difference between the two site class estimates (dependent samples two-tailed $t$-test, $\alpha=0.05$, $t=-8.972, p<0.001, d f=1,319$ ) (Table 4). Figure 5 shows the distribution of site class differences $\left(\mathrm{SC}_{\mathrm{INV}}-\mathrm{SC}_{\mathrm{LIDAR}}\right)$; the LIDAR-derived site classes were greater than the corresponding inventory site classes for $42 \%$ of stands. The majority of stands $(77 \%)$ were within \pm 1 class of the site class estimated from the original site-index values. Figure 6 illustrates the differences in site class by leading species (sample sizes in Table 1) and indicates that for all species, $\mathrm{SC}_{\mathrm{LIDAR}}$ was greater than $\mathrm{SC}_{\mathrm{INV}}$. Amabilis fir dominated stands had the greatest difference in site class, followed by western hemlock; Douglas-fir dominated stands had the smallest difference in site class.

\section{Estimation of stand biomass and C stocks}

Two separate model runs were conducted using the CBM-CFS3 model; all parameters were identical with the exception of site class. Figure 7
Fig. 3 Scatterplot showing SI $_{\text {INV versus }}$ SI LIDAR

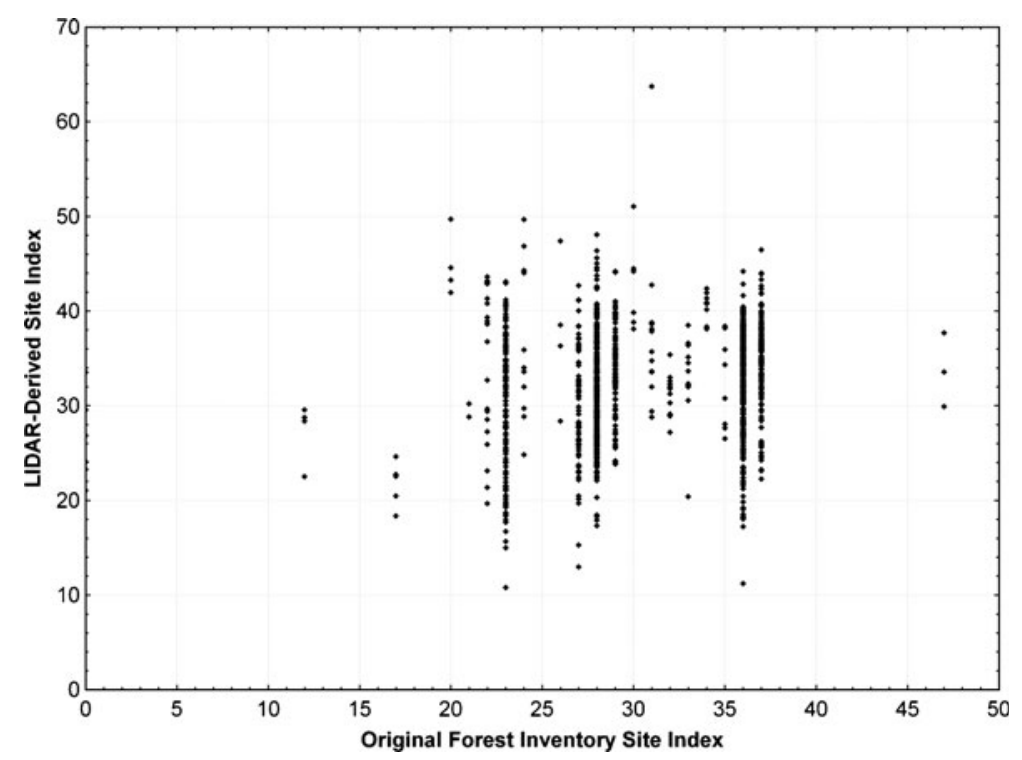


Fig. 4 Comparison of the distribution of site index estimates in the original inventory and those made using LIDAR-derived mean stand heights, by leading species. Sample sizes are provided in Table 1. Mean, mean \pm $\mathrm{SE}$ (box), and mean \pm 1 SD (whisker)

Table 4 Comparison of site index, site class, and biomass/ha, by leading species

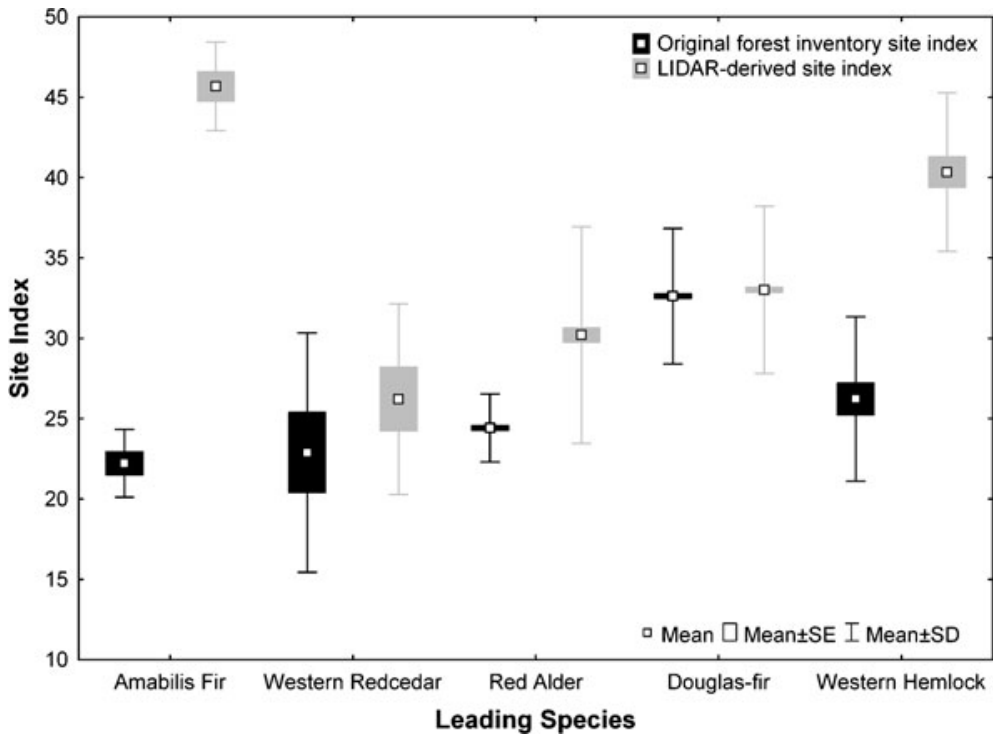

\begin{tabular}{|c|c|c|c|c|c|c|}
\hline Leading species & & Mean & SD & $\mathrm{t}$ & Df & $p$ \\
\hline \multicolumn{7}{|l|}{ Site index } \\
\hline \multirow[t]{2}{*}{ Amabilis fir } & $\mathrm{SI}_{\mathrm{INV}}$ & 22.22 & 2.11 & 23.791 & 8 & 0.000 \\
\hline & SI $_{\text {LIDAR }}$ & 45.67 & 2.75 & & & \\
\hline \multirow[t]{2}{*}{ Western red cedar } & $\mathrm{SI}_{\mathrm{INV}}$ & 22.88 & 7.44 & -2.286 & 8 & 0.052 \\
\hline & $\mathrm{SI}_{\text {LIDAR }}$ & 26.22 & 5.93 & & & \\
\hline \multirow[t]{2}{*}{ Red alder } & $\mathrm{SI}_{\mathrm{INV}}$ & 24.42 & 2.12 & -12.633 & 228 & 0.000 \\
\hline & $\mathrm{SI}_{\text {LIDAR }}$ & 30.19 & 6.75 & & & \\
\hline \multirow[t]{2}{*}{ Douglas-fir } & $\mathrm{SI}_{\mathrm{INV}}$ & 32.62 & 4.21 & -2.060 & 1045 & 0.039 \\
\hline & $\mathrm{SI}_{\text {LIDAR }}$ & 33.02 & 5.21 & & & \\
\hline \multirow[t]{2}{*}{ Western hemlock } & $\mathrm{SI}_{\mathrm{INV}}$ & 26.22 & 5.12 & -25.512 & 26 & 0.000 \\
\hline & SI $_{\text {LIDAR }}$ & 40.34 & 4.96 & & & \\
\hline \multicolumn{7}{|l|}{ Site class } \\
\hline \multirow[t]{2}{*}{ Amabilis fir } & $\mathrm{SI}_{\mathrm{INV}}$ & 22.78 & 2.64 & -18.81 & 8 & 0.000 \\
\hline & $\mathrm{SI}_{\text {LIDAR }}$ & 45.56 & 3.00 & & & \\
\hline \multirow[t]{2}{*}{ Western red cedar } & $\mathrm{SI}_{\mathrm{INV}}$ & 21.67 & 8.29 & -2.683 & 8 & 0.027 \\
\hline & $\mathrm{SI}_{\text {LIDAR }}$ & 26.67 & 5.59 & & & \\
\hline \multirow[t]{2}{*}{ Red alder } & $\mathrm{SI}_{\mathrm{INV}}$ & 25.09 & 1.55 & -11.922 & 228 & 0.000 \\
\hline & $\mathrm{SI}_{\text {LIDAR }}$ & 30.37 & 6.85 & & & \\
\hline \multirow[t]{2}{*}{ Douglas-fir } & $\mathrm{SI}_{\mathrm{INV}}$ & 32.60 & 3.04 & -2.167 & 1045 & 0.030 \\
\hline & $\mathrm{SI}_{\text {LIDAR }}$ & 33.01 & 5.53 & & & \\
\hline \multirow[t]{2}{*}{ Western hemlock } & $\mathrm{SI}_{\mathrm{INV}}$ & 27.78 & 6.41 & -16.901 & 26 & 0.000 \\
\hline & SI $_{\text {LIDAR }}$ & 40.74 & 4.94 & & & \\
\hline \multicolumn{7}{|l|}{ biomass/ha (tonnes) } \\
\hline \multirow[t]{2}{*}{ Amabilis fir } & $\mathrm{SI}_{\mathrm{INV}}$ & 109.55 & 0.45 & -3.811 & 8 & 0.005 \\
\hline & $\mathrm{SI}_{\text {LIDAR }}$ & 228.48 & 94.03 & & & \\
\hline \multirow[t]{2}{*}{ Western red cedar } & $\mathrm{SI}_{\mathrm{INV}}$ & 180.09 & 37.08 & -2.395 & 8 & 0.043 \\
\hline & $\mathrm{SI}_{\text {LIDAR }}$ & 209.40 & 20.13 & & & \\
\hline \multirow[t]{2}{*}{ Red alder } & $\mathrm{SI}_{\mathrm{INV}}$ & 134.59 & 49.75 & -8.914 & 228 & 0.000 \\
\hline & SI LIDAR $_{\text {LA }}$ & 150.72 & 63.64 & & & \\
\hline \multirow[t]{2}{*}{ Douglas-fir } & $\mathrm{SI}_{\mathrm{INV}}$ & 268.82 & 98.64 & -1.061 & 1045 & 0.288 \\
\hline & $\mathrm{SI}_{\text {LIDAR }}$ & 271.41 & 110.29 & & & \\
\hline \multirow[t]{2}{*}{ Western hemlock } & $\mathrm{SI}_{\mathrm{INV}}$ & 200.94 & 36.03 & -16.098 & 26 & 0.000 \\
\hline & $\mathrm{SI}_{\text {LIDAR }}$ & 349.95 & 32.97 & & & \\
\hline
\end{tabular}


Fig. 5 Distribution of the site class difference values (original site class-LIDAR-derived site class)

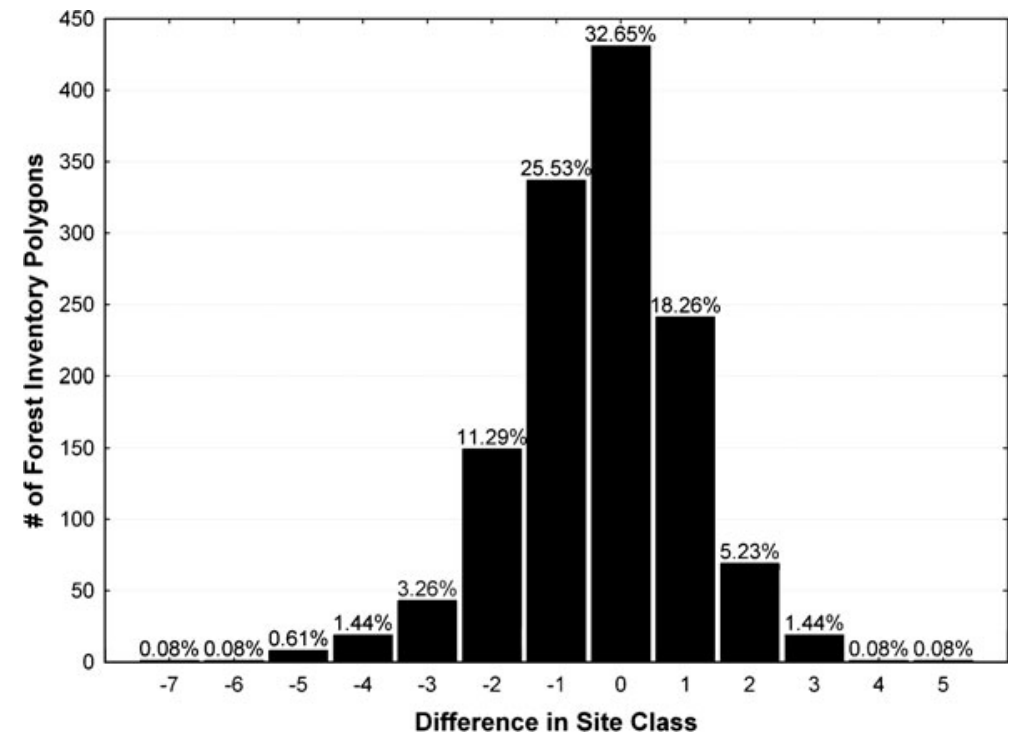

shows differences in the total biomass per hectare for the entire study area as modeled from 1920 to 2006. Total biomass does not differ greatly until the 1940s-most of the stands sampled were established in the 1940s, and when growth is modeled for these stands, the higher LIDAR site-index values (representing more favorable site conditions) result in greater estimates of biomass. Biomass estimates prior to 1940 were unaffected by differences in site index because site index was not used to assign yield tables to the old-growth stands that were present prior to logging. Instead, old-growth biomass in 1920 was estimated using stand-level merchantable volume estimates derived from a 1919 timber cruise as described by Trofymow et al. (2008). Old-growth biomass increments were simulated by assigning natural stand yield tables in a manner that provided appropriate starting volumes and subsequent annual increments that were consistent with our assumptions about oldgrowth biomass increments in these ecosystems.
Fig. 6 Distribution of site class difference values, by leading species (original site index-LIDAR site index). Mean, mean $\pm \mathrm{SE}$ (box), and mean $\pm 1 \mathrm{SD}$ (whisker)

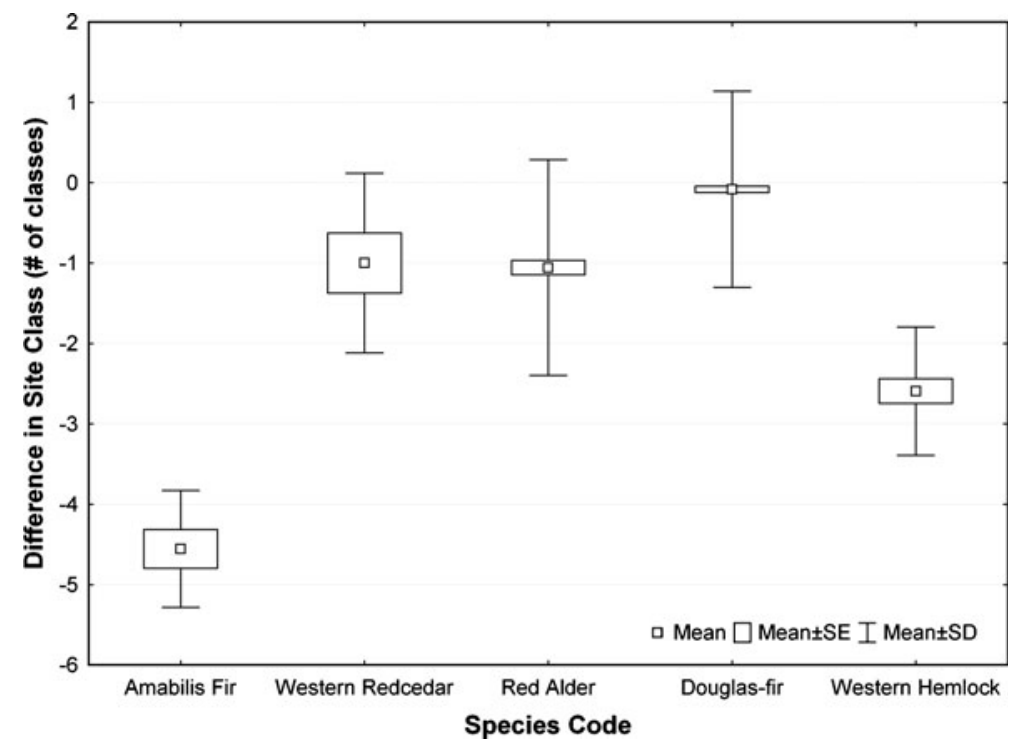


Fig. 7 Relationship between total study area biomass (in tonnes/ha) as estimated from the two separate CBM-CFS3 model runs. A model run estimated total annual biomass for each year from 1920 to 2006 and model inputs were identical with the exception of site index class

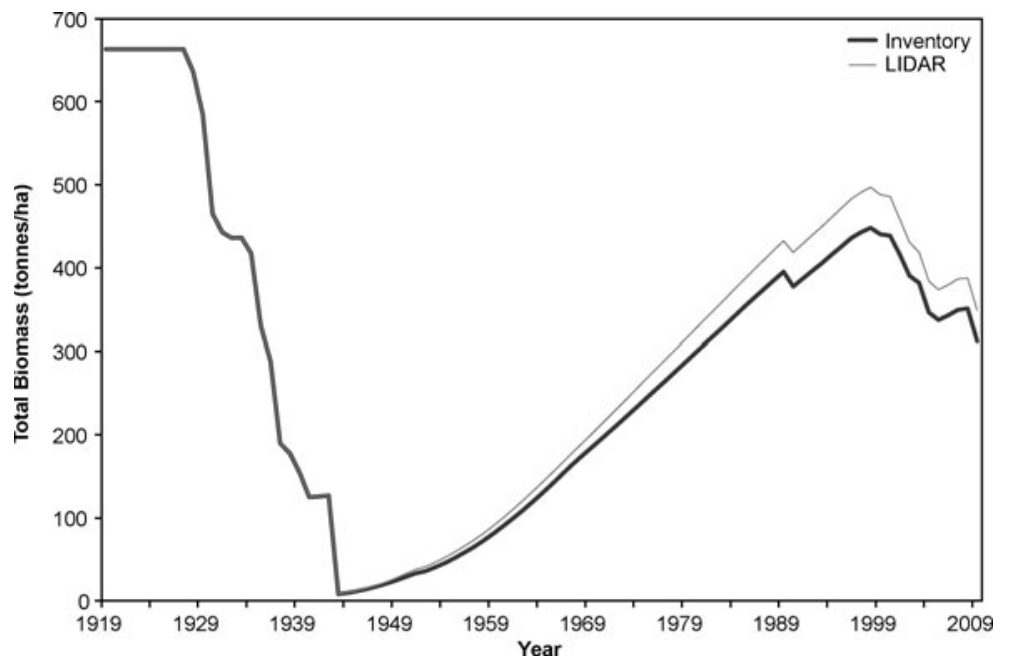

Once the stands were harvested, the old-growth stand attributes and natural stand yield table associations were replaced with stand attributes provided in the forest inventory data and the resulting managed stand yield table associations. Our biomass estimates for stands that were on site prior to the stands present in 2006 had no effect on our estimates of stand biomass in 2006. As expected, the different site class estimates used in the two model scenarios contribute to increasingly larger differences in biomass estimates over time.

Differences in biomass estimates between the two model scenarios in 2006 were statistically sig- nificant for both total stand biomass (dependent samples two-tailed t-test, $\alpha=0.05, t=-6.26, p<$ $0.001, d f=1,319)$ and stand biomass per ha (dependent samples two-tailed t-test, $\alpha=0.05, t=$ -4.28, $p<0.001, d f=1,319$ ) (Fig. 8). Total, above- and below-ground biomass in 2006 for the subset of stands considered in the analysis was 398,445 tonnes (242 tonnes per ha) for the inventory site-index scenario and 442,640 tonnes (269 tonnes/ha) for the LIDAR site index scenario. The total difference was 44,195 tonnes (27 tonnes/ha). The difference in estimated stand biomass per ha, by leading species, is illus-
Fig. 8 Distribution of biomass estimates (tonnes/ha), by leading species. Mean, mean $\pm \mathrm{SE}$ (box), and mean \pm 1 SD (whisker)

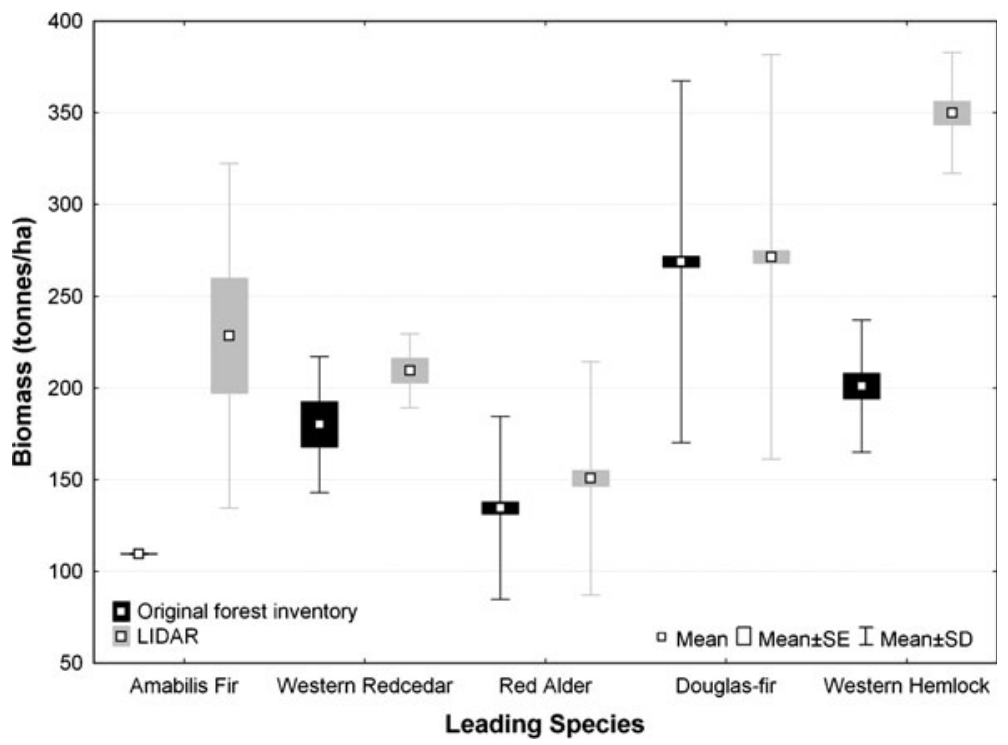


trated in Fig. 8. Significant differences in estimates of biomass per ha (dependent samples $t$ test, $\alpha=0.05)$ were found for amabilis fir ( $t=$ $-3.81, p=0.005, d f=8)$, western red cedar $(t=$ $-2.395, p=0.043, d f=8)$, red alder $(t=-8.913$, $p<0.001, d f=228)$, and western hemlock $(t=$ $-16.098, p<0.001, d f=26)$. The difference in biomass estimates for Douglas-fir were not statistically significant $(t=-1.061, p=0.288, d f=$ 1, 045) (Table 4).

\section{Discussion}

All of the stands included in our analysis were disturbed in the last 100 years, either by harvest or fire (the maximum age is 72 years), and while some of the stands were left to regenerate naturally, others were planted with Douglasfir, which is an important commercial species in Coastal British Columbia forests. Douglas-fir plantations have limited variation in tree size and have a more uniform structure than naturally regenerated stands (Wilson and Oliver 2000). Douglas-fir stands in our study area are more structurally uniform than stands dominated with cedar, hemlock, and red alder, which typically have greater diversity in stand composition, age, and height. The variability in the non-Douglasfir-dominated stands is most clearly evidenced by the differences in site class shown in Fig. 6 . These results not only indicate that mean stand heights, as calculated from the LIDAR, are representative of stand conditions in the more uniform Douglas-fir stands but also that height-age models of site index are best suited to these even-aged pure species stands (British Columbia Ministry of Forests 1999).

The implications of these findings are twofold. First, the use of LIDAR to capture local variability in stand height may be most useful in characterizing the site index of naturally regenerated stands or forest stands with more complex structure. Second, site index is dynamic (Skovsgaard and Vanclay 2007) and may require periodic update (Stearns-Smith 2001), as site index values in the forest inventory may not accurately reflect conditions for regenerating stands (Mah and Nigh 2003). LIDAR can be an effec- tive sampling tool (Reutebuch et al. 2005) and the use of LIDAR data to enhance the robustness of species-specific height-age methods (and other methods) of site index estimation warrants further investigation. Furthermore, methods have been developed to integrate LIDAR and optical imagery to obtain stand height and map aboveground biomass (St-Onge et al. 2008) and such an approach holds promise for areas such as Canada's north, where there is a lack of preexisting forest inventory and logistical challenges to acquiring aerial photography (Wulder et al. 2004; Gillis et al. 2005).

\section{Conclusions}

Two different methods of forest-stand site-index estimates were applied to the study area: the first method used original forest inventory site-index values and the second method used LIDARmeasured tree heights, combined with inventory information, to estimate site-index values. Significant differences were found between the original and LIDAR-derived site-index values for all species types and for the site class groupings derived from the estimates. Site classes were input into independent CBM-CFS3 model runs to generate stand-level estimates of biomass. Of the stands analyzed in this study (i.e., with a stand age between 30 and 140 years), $85 \%$ were dominated by Douglas-fir. For these stands, no significant difference was found between the biomass estimated from the original forest inventory site index and the LIDAR-derived site index (when estimates were normalized by stand area). Overall, the relationship between the two estimates of biomass are strong $\left(R^{2}=0.92, p<0.001\right)$, and the strength of this relationship suggests that LIDAR may have a role to play in site index estimation and biomass mapping in areas where there is no comprehensive forest inventory (assuming other data sources, such as optical remotely sensed data, can deliver the other attributes required for site index estimation), where an audit of site-index values is desired for operational or research purposes or where existing forest inventory site-index values are considered out-of-date. 
LIDAR may be a useful and economical source of calibration and validation data for site-index models across a range of species and sites and, as the results of this research suggest, may be particularly useful for characterizing the site index of naturally regenerated stands or stands with a more complex structure. Costs for LIDAR data acquisition and processing over large areas are currently high and may limit the application of LIDAR to that of a sampling tool for areas where current and site-specific estimates of site index can result in statistically significant refinements in biomass estimates. However, costs for transporting and maintaining ground crews in inaccessible areas are also high, and LIDAR may have a role to play in estimating stand heights and site index in these remote areas. Finally, the collection of aerial photography concurrently with LIDAR greatly expands the utility of the LIDAR data, facilitating the interpretation of range of forest attributes, including stand age, which is required for site-index estimation.

Acknowledgements Mark Gillis, of the Canadian Forest Service, is thanked for insights and assistance, particularly pertaining to forest inventory activities in Canada. The LIDAR data used in this study were made possible with funding from the Government of Canada through BIOCAP. Components of this research were funded by a DAAD post-graduate scholarship to Thomas Hilker (Germany) and NSERC funding to Benôit St. Onge and Nicholas Coops (Canada). Thanks to the staff and students with the Canadian Forest Service, including: Colin Ferster, Gurp Thandi, Simon Fodor, and Bruce Provan for processing the various historic maps and the current inventory coverage; Andrew Grieg for scanning and preparation of the historic orthophoto mosaics with advice from Don Leckie, Dean Hardman, Dennis Paradine, Morgan Cranny, and Francois Gougeon; Steve Taylor for access to the digital historic fire coverages; assistance from staff of the BCMoFR included Dave Spittlehouse, John Parminter for copies and advice on fire history maps, and Doug Say for access to provincial TRIM coverages and cadastral maps. We also acknowledge the support of the forest companies-Timberwest staff including Bill Grutzmacher for lending the historic timber cruise and forest cover maps, Clark Lowe and Don Davis for access to the 1999 orthophoto, current forest cover inventory, harvest, and fertilization coverages, and Jim MacPhalen for access to the growth and yield curves and advice on the inventory; and former Weyerhaeuser staff including Bill Beese and John Eden for advice and access to current inventory. Funding support for the inventory compilation and CBMCFS3 modeling came through Action Plan 2000, Panel on Energy Research and Development (PERD), B.C. Min- istry of Forests, and Ecosystem Processes Network to the Canadian Forest Service and the work represents a part of Natural Resources Canada's contribution to the Canadian Carbon Plan-Fluxnet-Canada Research Network.

\section{References}

Aalde, H., Gonzalez, P. M., Gytarsky, T., Krug, W. A., Kurz, S., Ogle, J., et al. (2006). Forest land. In H. S. Eggleston, L. Buendia, K. Miwa, T. Ngara \& K. Tanabe (Eds.), 2006 IPCC guidelines for national greenhouse gas inventories (pp 4.1-4.83). Hayama, Japan: IPCC National Greenhouse Gas Inventories Programme, Institute for Global Environmental Strategies.

Avery, T. E., \& Burkhart, H. E. (2002). Forest measurements (480 pp.). New York: McGraw-Hill.

Axelsson, P. (1999). Processing of laser scanner dataalgorithms and applications. ISPRS Journal of Photogrammetry and Remote Sensing, 54, 138-147. doi:10.1016/S0924-2716(99)00008-8.

Baldocchi, D. D. (2003). Assessing the eddy covariance technique for evaluating carbon dioxide exchange rates of ecosystems: Past, present, and future. Global Change Biology, 9, 479-492. doi:10.1046/ j.1365-2486.2003.00629.x.

Boudewyn, P., Song, X., Magnussen, S., \& Gillis, M. D. (2007). Model-based, volume-to-biomass conversion for forested and vegetated land in Canada. (124 pp.) Information Report BC-X-411, Natural Resources Canada, Canadian Forest Service, Pacific Forestry Centre, Victoria, British Columbia.

Boyer, W. D. (2001). A generational change in site index for naturally established longleaf pine on a south Alabama coastal plain site. Southern Journal of Applied Forestry, 25, 88-92.

British Columbia Ministry of Environment, Lands, and Parks (1992). British Columbia specifications and guidelines for geomatics. content series volume 3: Digital baseline mapping at 1:20 000, Release 2.0. Ministry of Environment, Lands, and Parks, Victoria, British Columbia, Canada. http://ilmbwww.gov. bc.ca/bmgs/pba/trim/specs/specs20.pdf. Accessed 24 July 2008.

British Columbia Ministry of Forests (1996). Variable density yield prediction (VDYP) batch application user guide. Version 6.3. (18 pp.). Victoria, British Columbia: Resources Inventory Branch.

British Columbia Ministry of Forests (1999). How to determine site index in silviculture? Participant's workbook. Forest Practices Branch, Victoria, British Columbia. http://www.for.gov.bc.ca/hfp/training/00011/ acrobat/sicourse.pdf. Accessed 24 July 2008.

British Columbia Ministry of Forests and Range (2004). SiteTools. Research Branch, Victoria, British Columbia http://www.for.gov.bc.ca/hre/sitetool/. Accessed 24 July 2008.

Bruce, D. (1981). Consistent height-growth and growthrate estimates for remeasured plots. Forest Science, 27, 711-725. 
Chen, Q., Gong, P., Baldocchi, D. D., \& Xie, G. (2007). Filtering airborne laser scanning data with morphological methods. Photogrammetric Engineering and Remote Sensing, 73, 171-181.

Clark, D. A., Brown, S., Kicklighter, D. W., Chambers, J. Q., Thomlinson, J. R., \& Ni, J. (2001). Measuring net primary production in forests: Concepts and field methods. Ecological Applications, 11, 356-370. doi:10. 1890/1051-0761(2001)011[0356:MNPPIF]2.0.CO;2.

Coops, N. C., Hilker, T., Wulder, M. A., St-Onge, B., Newnham, G., Siggins, A., et al. (2007). Estimating canopy structure of Douglas-fir forest stands from discrete-return LiDAR. Trees (Berlin), 21, 295-310. doi:10.1007/s00468-006-0119-6.

Demarchi, D. A. (1996). An introduction to the ecoregions of British Columbia. British Columbia Ministry of Environment, Lands and Parks, Victoria, British Columbia. http://www.llbc.leg.bc.ca/public/PubDocs/ bcdocs/325282/techpub_rn324.pdf. Accessed 24 July 2008.

Denman, K. L., Brasseur, G., Chidthaisong, A., Ciais, P., Cox, P. M., Dickinson, R. E., et al. (2007). Couplings between changes in the climate system and biogeochemistry. In S. Solomon, D. Qin, M. Manning, Z. Chen, M. Marquis, K. B. Averyt, M. Tignor \& H. L. Miller (Eds.), Climate change 2007: The physical science basis. Contribution of working group I to the fourth assessment report of the intergovernmental panel on climate change (996 pp.). Cambridge: Cambridge University Press.

Dubayah, R., \& Drake, J. B. (2000). Lidar remote sensing for forestry. Journal of Forestry, 98, 44-46.

Forest Productivity Council of British Columbia (1998a). Definition and estimation of top height for site index. Technical Advisory Committee. http://www.for. gov.bc.ca/hre/fpc/standards/topheight/index.htm. Accessed 24 July 2008.

Forest Productivity Council of British Columbia (1998b). Top height definition. Technical Advisory Committee. http://www.for.gov.bc.ca/hre/fpc/standards/top height/top_height.htm. Accessed 24 July 2008.

García, O., \& Batho, A. (2005). Top height estimation in lodgepole pine sample plots. Western Journal of Applied Forestry, 20, 64-68.

Gatziolis, D. (2007). LIDAR-derived site index in the U.S. pacific northwest-challenges and opportunities. In Proceedings of the ISPRS workshop on laser scanning 2007 and SilviLaser 2007, September 12-14 2007, IAPRS Volume XXXVI, Part 3, W52, 2007, (pp. 137143). Espoo: Finland.

Gillis, M. D., \& Leckie, D. (1996). Forest inventory update in Canada. Forestry Chronicle, 72, 138-156.

Gillis, M. D., Omule, A. Y., \& Brierly, T. (2005). Monitoring Canada's forests: The national forest inventory. Forestry Chronicle, 81, 214-221.

Green, R. N., \& Klinka, K. (1994). A field guide to site identification and interpretation for the Vancouver forest region: Land management handbook \#28. Ministry of Forests, Research Branch, Victoria, British Columbia. http://www.for.gov.bc.ca/hfd/pubs/ docs/Lmh/Lmh28.pdf. Accessed 24 July 2008.
Hägglund, B. (1981). Evaluation of forest site productivity. Forestry Abstracts, 42, 515-527.

Hall, R. J. (2003). The roles of aerial photographs in forestry remote sensing image analysis. In M. A. Wulder \& S. E. Franklin (Eds.), Remote sensing of forest environments: Concepts and case studies (pp. 4777). Boston: Kluwer.

Hamilton, J. G., DeLucia, E. H., George, K., Naidu, S. L., Finzi, A. C., \& Schlesinger, W. H. (2002). Forest carbon balance under elevated $\mathrm{CO}_{2}$. Oecologia, 131, 250-260. doi:10.1007/s00442-002-0884-x.

Hasenauer, H., \& Monserud, R. A. (1997). Biased predictions for tree height increment models developed from smoothed 'data'. Ecological Modelling, 98, 1322. doi:10.1016/S0304-3800(96)01933-3.

Heo, J., Park, J. S., Song, Y., Lee, S. K., \& Sohn, H. (2008). An integrated methodology for estimation of forest fire-loss using geospatial information. Environmental Monitoring and Assessment, 144, 285-299. doi:10.1007/s10661-007-9992-8.

Huang, S., Monserud, R. A., Braun, T., Lougheed, H., \& Bakowsky, O. (2004). Comparing site productivity of mature fire-origin and post-harvest juvenile lodgepole pine stands in Alberta. Canadian Journal of Forest Research, 34, 1181-1191. doi:10.1139/x04-009.

Humphreys, E. R., Black, T. A., Morgenstern, K., Cai, T., Drewitt, G., Nesic, Z., et al. (2006). Carbon dioxide fluxes in coastal Douglas-fir stands at different stages of development after clearcut harvesting. Agriculture and Forest Meterology, 140, 6-22. doi:10.1016/j.agrformet.2006.03.018.

Jungen, J. R. (1985). Soils of southern Vancouver island. British Columbia soil survey report 44. Ministry of environment technical report 17, $198 \mathrm{pp}$. British Columbia Ministry of Environment, Victoria, British Columbia. http://sis.agr.gc.ca/cansis/publications/bc/ bc44/bc44_report.pdf. Accessed 24 July 2008.

Kangas, A., Gove, J. H., \& Scott, C. T. (2006). Introduction. In A. Kangas \& M. Maltamo (Eds.), Forest inventory: methodology and applications (pp. 3-8). Dordrecht, Netherlands: Springer.

Kraus, K., \& Pfeiffer, N. (1998). Determination of terrain models in wooded areas with airborne laser scanner data. ISPRS Journal of Photogrammetry and Remote Sensing, 54, 193-203. doi:10.1016/ S0924-2716(98)00009-4.

Kull, S., Kurz, W. A., Rampley, G., Banfield, G. E., Schivatcheva, R. K., Apps, M. J. (2006). Operationalscale carbon budget model of the Canadian forest sector (CBM-CFS3) version 1.0 (320 pp.). Edmonton, Alberta: Natural Resources Canada, Canadian Forest Service, Northern Forestry Centre.

Kurz, W. A., \& Apps, M. J. (1999). A 70-year retrospective analysis of carbon fluxes in the Canadian forest sector. Ecological Applications, 9, 526-547. doi:10.1890/ 1051-0761(1999)009[0526:AYRAOC]2.0.CO;2.

Kurz, W. A., Apps, M. J., Banfield, E., \& Stinson, G. (2002). Forest carbon accounting at the operational scale. Forestry Chronicle, 78, 672-679.

Kurz, W. A., Apps, M. J., Webb, T. M., \& McNamee, P. J. (1992). The carbon budget of the Canadian 
Forest Sector: Phase I. Information Report NOR-X326, Edmonton, Alberta: Forestry Canada, Northwest Rregion, Northern Forestry Centre.

Lal, R., Kimble, J. M., Follett, R. F., \& Stewart, B. A. (2001). Assessment methods for soil carbon (advances in soil science) (696 pp.). Boca Raton, Florida: Lewis Press.

Landsberg, J. (2003). Modelling forest ecosystems: State of the art, challenges, and future directions. Canadian Journal of Forest Research, 33, 385-397. doi:10.1139/x02-129.

Lefsky, M., Turner, D., Guzy, M., \& Cohen, W. (2005). Combining lidar estimates of aboveground biomass and landsat estimates of stand age for spatially extensive validation of modeled forest productivity. Remote Sensing of Environment, 95, 549-558. doi:10.1016/j.rse.2004.12.022.

Li, Z., Kurz, W. A., Apps, M. J., \& Beukema, S. J. (2003). Belowground biomass dynamics in the carbon budget model of the Canadian Forest Sector: Recent improvements and implications for the estimation of NPP and NEP. Canadian Journal of Forest Research, 33, 126-136. doi:10.1139/x02-165.

Lim, K., Treitz, P., Wulder, M. A., St-Onge, B., \& Flood, M. (2003). LIDAR remote sensing of forest structure. Progress in Physical Geography, 27, 88-106. doi:10.1191/0309133303pp360ra.

Lovell, J. L., Jupp, D. L. B., Newnham, G. J., Coops, N. C., \& Culvenor, D. S. (2005). Simulation study for finding optimal LIDAR acquisition parameters for forest height retrieval. Forest Ecology and Management, 214, 398-412. doi:10.1016/j.foreco.2004.07.077.

Magnussen, S. (1999). Effect of plot size on estimtes of top height in Douglas-fir. Western Journal of Applied Forestry, 14, 17-27.

Magnussen, S., \& Boudewyn, P. (1998). Derivations of stand heights from airborne laser scanner data with canopy-based quantile estimators. Canadian Journal of Forest Research, 28, 1016-1031. doi:10.1139/ cjfr-28-7-1016.

Magnussen, S., Eggermont, P., \& LaRiccia, V. (1999). Recovering tree heights from airborne laser scanner data. Forest Science, 45, 407-422.

Mah, S., \& Nigh, G. D. (2003). SIBEC site index estimates in support of forest management in British Columbia. Technical report 004. Research Branch, British Columbia Ministry of Forests, Victoria, British Columbia. http://www.for.gov.bc.ca/hfd/pubs/ Docs/Tr/Tr004.pdf. Accessed 24 July 2008.

McRoberts, R. E., \& Tomppo, E. O. (2007). Remote sensing support of national forest inventories. Remote Sensing of Environment, 110, 412-419. doi:10.1016/ j.rse.2006.09.034.

Mitchell, K. J., Stone, M., Grout, S. E., Di Lucca, M., Nigh, G. D., Goudie, J. W., et al. (2000). TIPSY version 3.0. Ministry of Forests, Research Branch, Victoria, British Columbia. http://www.for.gov.bc.ca/ hre/gymodels/tipsy/. Accessed 24 July 2008.

Næsset, E. (1997). Determination of mean tree height of forest stands using airborne laser scanner data. ISPRS
Journal of Photogrammetry and Remote Sensing, 52, 49-56. doi:10.1016/S0924-2716(97)83000-6.

Næsset, E. (2002). Predicting forest stand characteristics with airborne scanning laser using a practical two-stage procedure and field data. Remote Sensing of Environment, 80, 88-99. doi:10.1016/ S0034-4257(01)00290-5.

Næsset, E., \& Økland, T. (2002). Estimating tree height and tree crown properties using airborne scanning laser in a boreal nature reserve. Remote Sensing of Environment, 79, 105-115. doi:10.1016/S0034-4257(01) 00243-7.

Næsset, E., Bollandsas, O., \& Gobakken, T. (2005). Comparing regression methods in estimation of biophysical properties of stands from two different inventories using laser scanner data. Remote Sensing of Environment, 94, 541-553. doi:10.1016/j.rse.2004.11.010.

Nelson, R., Valenti, M., Short, A., \& Keller, C. (2003). A multiple resource inventory of Deleware using airborne laser data. Bioscience, 53, 981-992. doi:10.1641/ 0006-3568(2003)053[0981:AMRIOD]2.0.CO;2.

Nigh, G. D., \& Courtin, P. J. (1998). Height models for red alder (Alnus rubra Bong) in British Columbia. New Forests, 16, 59-70. doi:10.1023/A:1006561502635.

Nigh, G. D., \& Love, B. (1999). A model for estimating juvenile height of lodgepole pine. Forest Ecology and Management, 123, 157-166. doi:10.1016/ S0378-1127(99)00019-5.

Nigh, G. D., \& Mitchell, M. G. E. (2003). Development of height-age models for estimating juvenile height of coastal Douglas-fir in British Columbia. Western Journal of Applied Forestry, 18, 207-212.

Ni-Meister, W., Jupp, D. L., \& Dubayah, R. (2001). Modeling LIDAR waveforms in heterogeneous and discrete caopies. Geoscience and Remote Sensing, 39, 19431957. doi:10.1109/36.951085.

Nussbaum, A. F. (1998). Site index adjustments for old-growth stands based on paired plots. Research Branch, British Columbia Ministry of Forests, Victoria, British Columbia. Working Paper 37. http://www.for.gov.bc.ca/hfd/pubs/docs/Wp/Wp37.pdf. Accessed 24 July 2008.

Persson, A., Holmgren, J., \& Soderman, U. (2002). Detecting and measuring individual trees using an airborne laser scanner. Photogrammetric Engineering and Remote Sensing, 68, 925-932.

Pojar, J., Klinka, K., \& Demarchi, D. A. (1991). Coastal western Hemlock zone. In D. Meidinger \& J. Pojar (Eds.), Ecosystems of British Columbia, BC Special Report Series No. 6 (pp 95-111). Victoria, British Columbia: British Columbia Ministry of Forests.

Popescu, S. C. (2007). Estimating biomass of individual pine trees and tree components using airborne LiDAR. Biomass \& Bioenergy, 31, 646-655. doi:10.1016/j.biombioe.2007.06.022.

Popescu, S. C., \& Wynne, R. H. (2004). Seeing the trees in the forest: Using lidar and multispectral data fusion with local filtering and variable window size for estimating tree height. Photogrammetric Engineering and Remote Sensing, 70, 589-604. 
Popescu, S. C., Wynne, R. H., \& Nelson, R. F. (2002). Estimating plot-level tree heights with lidar: Local filtering with a canopy height based variable window size. Computers and Electronics in Agriculture, 37, 71-95. doi:10.1016/S0168-1699(02)00121-7.

Reutebuch, S. E., Andersen, H. E., \& McGaughey, R. J. (2005). Light detection and ranging (LIDAR): An emerging tool for multiple resource inventory. Journal of Forestry, 103, 286-292.

Reutebuch, S. E., McGaughey, R. J., Anderson, H. E., \& Carson, W. W. (2003). Accuracy of a highresolution LIDAR terrain model under a conifer forest canopy. Canadian Journal of Remote Sensing, 29, $527-535$.

Roggero, M. (2001). Airborne laser scanning: Clustering in raw data. International Archives of the Photogrammetry, Remote Sensing and Spatial Information Sciences, $X X X I V-3(\mathrm{~W} 4), 227-232$.

Running, S., Baldocchi, D., Turner, D., Gower, S., Bakwin, P., \& Hibbard, K. (1999). A global terrestrial monitoring network integrating tower fluxes, flask sampling, ecosystem modeling and EOSD satellite data. Remote Sensing of Environment, 70, 108-127. doi:10.1016/S0034-4257(99)00061-9.

Sharma, M., \& Parton, J. (2007). Height-diameter equations for boreal tree species in Ontario using a mixed-effects modeling approach. Forest Ecology and Management, 249, 187-198. doi:10.1016/j. foreco.2007.05.006.

Sithole, G., \& Vosselman, G. (2004). Experimental comparison of filter algorithms for bare-Earth extraction from airborne laser scanning point clouds. ISPRS Journal of Photogrammetry and Remote Sensing, 59, 85-101. doi:10.1016/j.isprsjprs.2004. 05.004.

Skovsgaard, J. P., \& Vanclay, J. K. (2007). Forest site productivity: A review of the evolution of dendrometric concepts for even-aged stands. Forestry, 81, 13-31. doi:10.1093/forestry/cpm041.
Stearns-Smith, S. (2001). Making sense of site index estimates in British Columbia: A quick look at the big picture. BC Journal of Ecosystems and Management, 1,1-4.

St-Onge, B., Hu, Y., \& Vega, C. (2008). Mapping the height and aboveground biomass of mixed forest using lidar and stereo Ikonos images. International Journal of Remote Sensing, 29, 1277-1294. doi:10.1080/01431160701736505.

St-Onge, B., Jumelet, J., Cobello, O., \& Vega, C. (2004). Measuring individual tree height using a combination of stereophotogrammetry and lidar. Canadian Journal of Forest Research, 34, 2122-2130. doi:10.1139/x04-093.

St-Onge, B., Treitz, P., \& Wulder, M. A. (2003). Tree and canopy height estimation with scanning LIDAR. In M. A. Wulder \& S. E. Franklin (Eds.), Remote sensing of forest environments: Concepts and case studies (pp. 489-510). Boston, Massachusettes: Kluwer Academic Publishers.

Trofymow, J. A., Stinson, G., \& Kurz, W. (2008). Derivation of a spatially-explicit 86-year retrospective carbon budget for a landscape undergoing conversion from old-growth to managed forests on Vancouver island. Forest Ecology and Management, 256, 16771691. http://dx.doi.org/10.1016/j.foreco.2008.02.056.

Véga, C., \& St-Onge, B. (2008). Height growth reconstruction of a boreal forest canopy over a period of 58 years using a combination of photogrammetric and lidar models. Remote Sensing of Environment, 112, 17841794. doi:10.1016/j.rse.2007.09.002.

Wilson, J. S., \& Oliver, C. D. (2000). Stability and density management in Douglas-fir plantations. Canadian Journal of Forest Research, 30, 910-920. doi:10.1139/ cjfr-30-6-910.

Wulder, M. A., Kurz, W. A., \& Gillis, M. (2004). National level forest monitoring and modeling in Canada. Progress in Planning, 61, 365-381. doi:10.1016/ S0305-9006(03)00069-2. 